\title{
Optimization of process parameters on friction stir welding of 2014 aluminum alloy plates
}

\author{
V. Jaiganesh ${ }^{1 *}$, D. Srinivasan ${ }^{2}$, P. Sevvel ${ }^{3}$

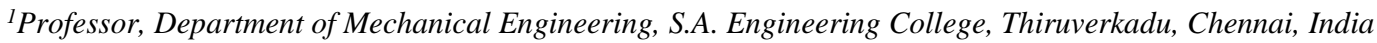 \\ ${ }^{2}$ Associate Professor, Department of Mechanical Engineering, S.A. Engineering College, Thiruverkadu, Chennai, India \\ ${ }^{3}$ Professor, Department of Mechanical Engineering, S.A. Engineering College, Thiruverkadu, Chennai, India \\ *Corresponding author E-mail: drjai@saec.ac.in
}

\begin{abstract}
Aluminum Alloy 2014 is a light weight high strength alloy used widely in the aerospace and also in other industries. 2014 is the second most popular of the 2000-series aluminium alloys, after 2024 aluminium alloy. However, it is difficult to weld, as it is subject to cracking. Joining of 2014 aluminium alloy in friction stir welding which is based on frictional heat generated through contact between a rotating tool and the work piece. Determination of the welding parameters such as spindle speed, transverse feed, tilt angle plays an important role in weld strength. The whole optimization process is carried out using Taguchi technique. The SEM analysis is done to check the micro structure of the material after welding by electron interaction with the atoms in the sample. Tensile test have been conducted and the s-n ratio curve is generated. The test is conducted and analysed on the basis of ASTM standards.
\end{abstract}

Keywords: Friction stir welding, aluminium 2014 Alloy, optimization of process parameters, tensile strength.

\section{Introduction}

Friction Stir Welding is a solid state welding process used to perform high quality lap and butt joints increasingly used in aircraft and ship building industry to join materials which are difficult to weld using conventional welding techniques [1 - 3] Defects such as distortion and porosity in conventional welding process are minimized in FSW [4 - 7] Finding the most effective parameters for better welding properties have been the major topic in research.

\section{Materials and methods}

\subsection{Materials used in the welding process}

The materials used in this welding process in aluminum alloy 2014. This alloy is mainly used in manufacturing of rims of the aircrafts and used in the manufacturing of car chasis. The major drawback of conventional welding AA2014 is the material melts at the temperature above $873 \mathrm{~K}$. So, unconventional welding technique such as Friction stir welding is employed. The chemical properties of AA2014 are shown in the Table 1 and the physical properties of AA2014 are shown in Table 2.

Table 1: Chemical Properties of AA2014 Wrought Aluminum Alloy

\begin{tabular}{|l|l|l|l|l|l|l|l|l|l|l|l|l|}
\hline Element & $\mathrm{Si}$ & $\mathrm{Fe}$ & $\mathrm{Cu}$ & $\mathrm{Mn}$ & $\mathrm{Mg}$ & $\mathrm{Zn}$ & $\mathrm{Cr}$ & $\mathrm{Ni}$ & $\mathrm{Ti}$ & $\mathrm{Sn}$ & $\mathrm{Al}$ \\
\hline$\%$ & 0.622 & 0.292 & 4.259 & 0.513 & 0.419 & 0.014 & 0.024 & 0.013 & 0.031 & 0.005 & 93.808 \\
\hline
\end{tabular}

Table 2: Physical Properties of AA2014 Heavy Extrusion Bar

\begin{tabular}{|c|c|c|c|c|c|c|c|c|}
\hline Table 2: Physical Properties of AA2014 Heavy Extrusion Bar \\
\hline $2.8 \times 10^{5} \mathrm{~kg} / \mathrm{m}^{3}$ & Poisson Ratio & Elastic Modulus & Tensile Strength & Yield Strength & Melting Point & Hardness & Shear Strength & Failure Strength \\
\hline
\end{tabular}

\subsection{Optimization technique}

The method used for the optimization process is Taguchi technique. The Taguchi technique is widely used for finding the optimum values in the parameter design [ $8-10]$. In this process considering three parameters and three level of variations Taguchi L9 orthogonal array is selected. Hence three input parameters such

as speed, feed rate and tilt angle is used for welding and the response factors such as tensile strength, yield strength and \% elongation are taken as response factors to determine the optimum value. Therefore optimum welding conditions can be determined by 9 trials.

L9 orthogonal array $3^{\wedge} 3=9$ trials ( 3 factors, 3 response)

The larger the better criterion is applied to the $\mathrm{S} / \mathrm{N}$ ratio, where the maximization of the response is required for the output characteristics data. The data of the target value is positive. Here the optimized result needed is higher tensile strength, yield strength, \% elongation and hence this criterion is selected to find out the optimum process parameter, which can give better strength. The following formula is used to find the optimum result,

$$
\mathrm{S} / \mathrm{N} \text { ratio }(\eta)=-10 \log 10\left((1 / \mathrm{n}) \Sigma\left(1 /\left(\mathrm{y}_{\mathrm{ij}}\right) 2\right)\right)
$$


The value of the response table for the mean and $\mathrm{S} / \mathrm{N}$ ratio is evaluated by the MINITAB software and it can be verified by using the above equation.

\subsection{Tool used}

Different types of tool profiles are used in this welding of aluminium alloy .The types of profiles more commonly used in friction stir welding are straight cylindrical, tapered cylindrical, cylindrical grooved. These tool profiles are machined in a CNC turning lathe and optical profile grinding is done to achieve an accuracy of $\pm .001 \mathrm{~m}$. A tapered cylindrical tool with the tool dimensions of diameter shoulder of $15 \mathrm{~mm}$ and a min diameter of $5 \times 3 \mathrm{~mm}$ and $4.7 \mathrm{~mm}$ height which is machined from HSS steel and the tool is subjected to a heat treatment of 65HRC (Rockwell hardness scale C). The image of the tool used is shown in the Fig. 1 .

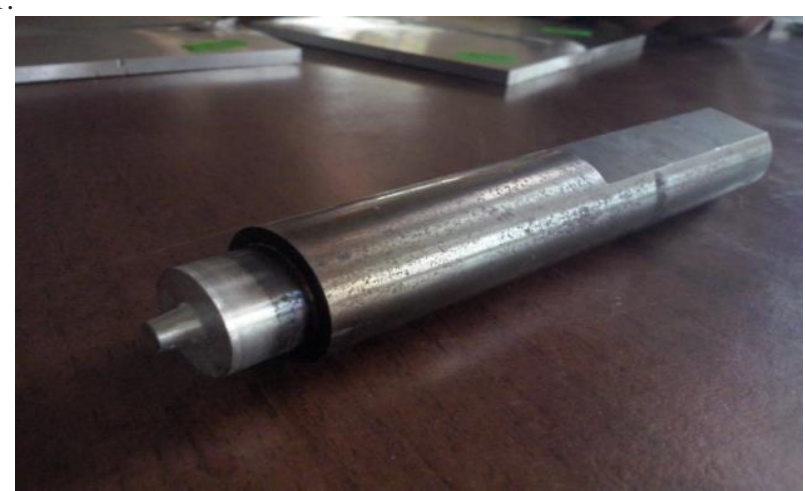

Fig. 1: Image of the tool

\subsection{Friction stir welding}

Two Plates of the dimension of $100 \times 50 \times 5 \mathrm{~mm}$ are clamped in the fixture and the welding process is carried out according to the combination according to the Taguchi orthogonal array. The table of the various parameters and the three levels are shown in the Table 3. An image of the samples that were welded by Friction Stir Welding is shown in the Fig. 2.

Table 3: Parameters and Three Level of Values

\begin{tabular}{|l|l|l|l|}
\hline Factors & 1 & 2 & 3 \\
\hline Spindle speed $[\mathrm{rpm}]$ & 800 & 1000 & 1200 \\
\hline Feed rate $[\mathrm{mm} / \mathrm{min}]$ & 5 & 10 & 15 \\
\hline Tilt angle $[\Phi]$ & 0 & 1 & 1 \\
\hline
\end{tabular}

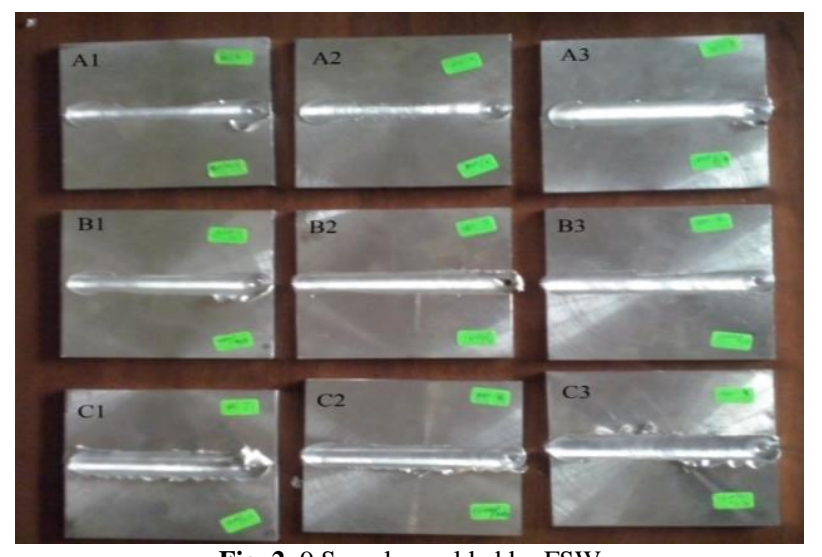

Fig. 2: 9 Samples welded by FSW

\section{Results and discussions}

\subsection{Testing and analysis}

Thus the nine set of welded plates. The dimension of the welded plate is $100 \times 100 \times 5 \mathrm{~mm}$. For this dimension according to ASTM
E8 standards [9]. ASTM E 8 describes tension testing methods to determine yield strength, yield strength, $\%$ elongation of the aluminum alloy [11 - 13]. The image of the I-Section for Tensile Testing Based on ASTM standards for $100 \times 100 \mathrm{~mm}$ is shown in the Fig. 3. The image of the I-sections made from the welded plates is shown in the Fig. 4.

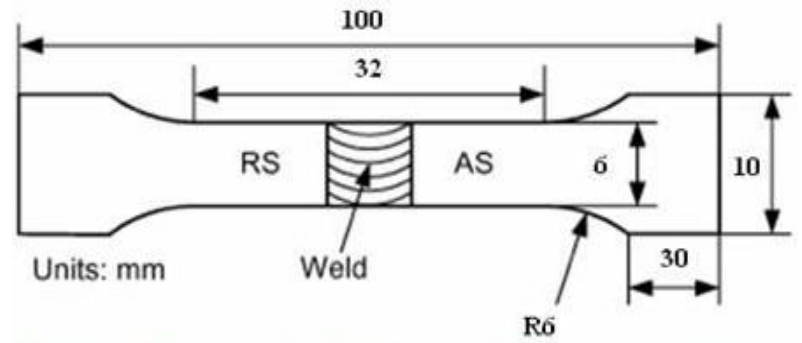

Fig. 3: ASTM E8 standard I-Section for tensile testing

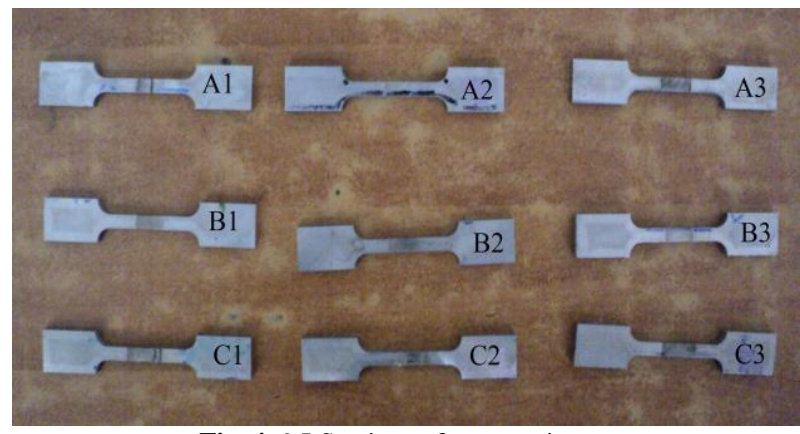

Fig. 4: 9 I-Sections of test specimens

Tensile testing has been carried out and the corresponding tensile strength, yield strength, \% elongation are discussed below in Table 4.

\begin{tabular}{|l|l|l|l|l|l|l|}
\multicolumn{7}{|c|}{ Table 4: Tensile Testing Results } \\
\begin{tabular}{|l|l|l|l|l|l|} 
Test \\
Specimen
\end{tabular} & $\begin{array}{c}\text { Speed } \\
(\mathrm{rpm})\end{array}$ & $\begin{array}{c}\text { Feed Rate } \\
\mathrm{mm} / \mathrm{min}\end{array}$ & $\begin{array}{c}\text { Tilt } \\
\text { angle } \\
(\Phi)\end{array}$ & $\begin{array}{c}\text { Tensile } \\
\text { Strength } \\
(\mathrm{Mpa})\end{array}$ & $\begin{array}{c}\text { Yield } \\
\text { Strength } \\
(\mathrm{Mpa})\end{array}$ & $\begin{array}{c}\text { Percentage } \\
\text { Elongation } \\
(\%)\end{array}$ \\
\hline 1 & 800 & 5 & 0 & 81.39 & 61.21 & 4.10 \\
\hline 2 & 800 & 10 & 1 & 55.56 & 49.47 & 5.50 \\
\hline 3 & 800 & 15 & 1 & 108.52 & 93.19 & 6.92 \\
\hline 4 & 1000 & 5 & 1 & 74.49 & 67.39 & 4.08 \\
\hline 5 & 1000 & 10 & 1 & 197.64 & 168.13 & 5.64 \\
\hline 6 & 1000 & 15 & 0 & 67.26 & 60.58 & 6.0 \\
\hline 7 & 1200 & 5 & 1 & 81.04 & 72.64 & 4.12 \\
\hline 8 & 1200 & 10 & 0 & 128.75 & 120 & 5.40 \\
\hline 9 & 1200 & 15 & 1 & 235.92 & 204.44 & 6.4 \\
\hline
\end{tabular}

\subsection{Optimized results}

The tensile reports show that the combination of feed $15 \mathrm{~mm} / \mathrm{min}$ and tilt angle of $1^{\circ}$ have greater weld strength. However speed of $1000 \mathrm{rpm}, 10 \mathrm{~mm} / \mathrm{min}$ feed and $1^{\circ}$ have a weld strength of $197 \mathrm{Mpa}$ which also contributes to $50 \%$ of parent strength yet max strength is considered to be the optimum value. The $\mathrm{S} / \mathrm{N}$ ratio generated to show larger is better, clearly indicates that speed has a major impact over the weld strength out of the speed range of $800,1000,12001200$ lies the better value , feed rate of $15 \mathrm{~mm} / \mathrm{min}$ and tilt angle of $1^{\circ}$ have the larger values hence the optimum conditions for obtaining the maximum weld strength a . Weld strength of tensile of $235 \mathrm{MPa}$ which is around $63 \%$ of the parent material which has strength of $370 \mathrm{Mpa}$. The main effects plots for $\mathrm{SN}$ ratios are shown in the Fig. 5 . 


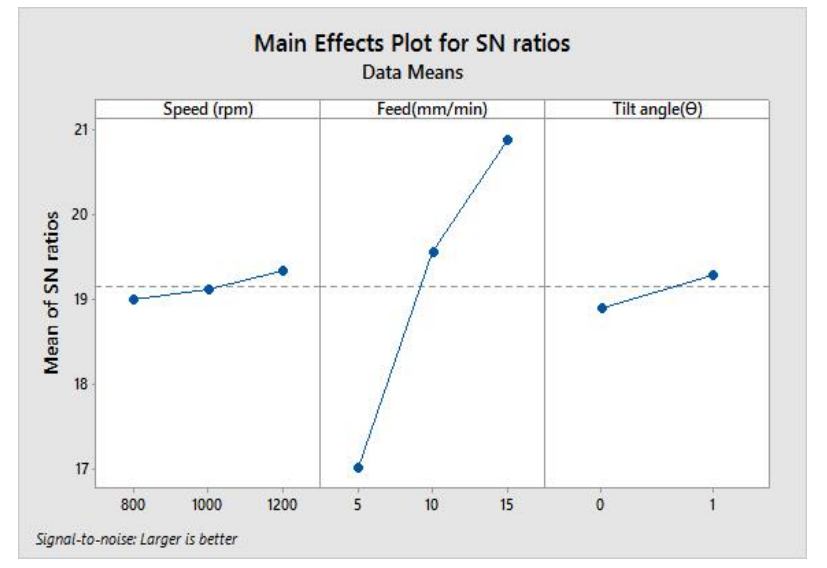

Fig. 5: Main effects plots for SN ratios

\section{Conclusion}

The welding of the 2014 aluminium alloy plates were carried out and done successfully. The optimization of the process parameters were done for the parameters speed, feed rate and tilt angle and the testing was carried out for the specimens. The Taguchi L9 orthogonal array was the technique that was chosen to optimize the process parameters. The results like Tensile Strength, Yield Strength and percentage elongation for all the 9 specimens were also obtained and they were compared with many graphs like SN ratios, etc. The best results were obtained for the parameters of $1200 \mathrm{rpm}$ of speed, $15 \mathrm{~mm} / \mathrm{min}$ of feed rate and $1^{\circ}$ of tilt angle. The best results that were obtained for the process are tensile strength of $235.92 \mathrm{MPa}$, yield strength of $204.44 \mathrm{MPa}$ and percentage elongation of $6.4 \%$. Since, the 2014 aluminium alloy finds a wide range of application in the aerospace and also other industries, where the joining of the materials are in a great need, the welding of the these materials by the process of Friction Stir Welding will be of great potential to the industries. Thus, the joined materials could be incorporated in the real time application and the testing could be carried out.

\section{References}

[1] Liu D, Xin R, Sun L, Zhou Z \& Liu Q, "Influence of sampling design on tensile properties and fracture behavior of friction stir welded magnesium alloys", Materials Science \& Engineering A, Vol.576, (2013), pp.207-216.

[2] Sevvel P \& Jaiganesh V, "Effect of Tool Shoulder Diameter to Plate Thickness Ratio on Mechanical Properties and Nugget Zone Characteristics During FSW of Dissimilar Mg Alloys", Transactions of the Indian Institute of Metals, Vol.68, (2015), pp.41-46.

[3] Sutton MA, Reynolds AP, Yang B \& Taylor R, "Mode I fracture and microstructure for 2024-T3 friction stir welds", Materials Science and Engineering A, Vol.A354, (2003), pp.6-16.

[4] Sevvel P \& Jaiganesh V, "Investigation on evolution of microstructures and characterization during FSW of AZ80A Mg alloy", Archives of Metallurgy and Materials, Vol.62, No.3, (2017), pp.1779-1785.

[5] Ozel T \& Karpat Y, "Predictive modelling of surface roughness and tool wear in hard turning using regression and neural networks", International Journal of Machine Tools and Manufacture, Vol.45, (2005), pp.467-479.

[6] Feng CX \& Wang X, "Development of empirical model for surface roughness prediction in finish turning", International Journal of Advanced Manufacturing Technology, Vol.20, (2002), pp.348-356.

[7] Ramanujam R, Venkatesan K, Saxena V, Pandey R, Harsha T \& Kumar G, „Optimization of Machining Parameters Using Fuzzy Based Principal Component Analysis during dry turning operation of Inconel 625-A hybrid approach“, Procedia Engineering,Vol.97, (2014), pp.668-676.

[8] Vimalkumar, M.N., Helenprabha, K., Surendar, A."Classification of mammographic image abnormalities based on emo and LS-SVM techniques",(2017) Research Journal of Biotechnology, 12 (1), pp. 35-40.

[9] Manju, K., Sabeenian, R.S., Surendar, A.”A review on optic disc and cup segmentation",(2017) Biomedical and Pharmacology Journal, 10 (1), pp. 373-379.

[10] Surendar, A., Rani, N.U."High speed data searching algorithms for DNA searching",(2016) International Journal of Pharma and Bio Sciences, 2016 (Special Issue), pp. 73-77.

[11] Surendar, A., Arun, M."Efficient DNA sequence analysis for reduced gene selection using frequency analysis", (2016) Journal of Chemical and Pharmaceutical Sciences, 9 (4), pp. 3367-3373.

[12] Surendar, A., George, A."A real-time searching and sequencing assembly platform based on an FPGA implementation for Bioinformatics applications",(2016) International Journal of Pharma and Bio Sciences, 7 (4), pp. B642-B647.

[13] Zeng R, Dietzel W, Zettler R, Chen J \& Kainer KU, "Microstructure evolution and tensile properties of friction-stirwelded AM50 magnesium alloy", Transactions of Nonferrous Metals Society of China, Vol.18, (2008), pp.S76-S80.

[14] Sevvel P \& Jaiganesh V, "A detailed investigation on the role of different tool geometry in friction stir welding of various metals \& their alloys", Proceedings of the International Colloquium on 'Materials, manufacturing \& metrology', (2014), pp.103-107.

[15] Liu D, Xin R, Sun L, Zhou Z \& Liu Q, "Influence of sampling design on tensile properties and fracture behavior of friction stir welded magnesium alloys", Materials Science \& Engineering A, Vol.576, (2013), pp.207-216.

[16] Jiang JF, Lin X, Wang Y, Qu JJ \& Luo SJ, "Microstructural evolution of AZ61 magnesium alloy predeformed by ECAE during semisolid isothermal treatment", Transactions of Nonferrous Metals Society of China, Vol.22, No.3, (2012), pp.555-563.

[17] Sevvel P \& Jaiganesh V, "An detailed examination on the future prospects of friction stir welding-a green technology", Proceedings of the International conference on advances in industrial engineering applications, Chennai, India, (2014), pp.62-63.

[18] Yu S, Chen X, Huang Z \& Liu Y, "Microstructure and mechanical properties of friction stir welding of AZ31B magnesium alloy added with cerium", Journal of Rare Earths, Vol.28, (2010), pp.316-320. 